\title{
Thirsty Textile and Fashion Industry PART I: Water Distribution on Earth and Virtual Water, Water Footprint Concepts
}

\author{
RB Chavan* \\ Department of Textile Technology, Indian Institute of Technology, New Delhi, India
}

Received: 钢 September 25, 2018; Published: 監 October 15, 2018

*Corresponding author: RB Chavan, Retired Professor, Department of Textile Technology, Indian Institute of Technology, Delhi, India

\begin{abstract}
Textile and fashion industry is the thirstiest for water as it is one of the largest water consumers from fibre production to finished product. Unfortunately, all the scientific reports and opinions of renowned water experts are predicting the severe water scarcity in the near future in many parts of world particularly the developing countries where textile and fashion industry production activities are located because of cheap labour and less stringent environmental laws. The gloomy picture of water scarcity is good enough to caution the textile and fashion industry to take appropriate measures to use the water resources sustainably and make all efforts to save water at every stage of supply chain.

In the first part of this series attempt has been made to provide a critical review of water distribution on earth, inequitable water distribution in different regions of world and predictions on the dangers of water scarcity which the humanity is going to face in the near future. In order to face the situation of water scarcity scientific community is working on developing concepts and tools for sustainable water management. In this first part of the series, the development of virtual water and water footprint concepts have been highlighted. Water footprint concept is further elaborated with water footprint analysis, pointing out difference between virtual water and water footprint concept and how these two concepts are used synonymously, comparison of water footprint concept with carbon footprint, ecological footprint and life cycle analysis concepts, environment impact and strategies to reduce environment impact, criticism on water footprint concept and the various other tools developed for sustainable water management and certification and labelling. The subsequent parts of the series will highlight the water footprint of textile and fashion industry from fibre production to finished product stages.
\end{abstract}

Keywords: Water distribution on earth; Climate change; Water scarcity; Virtual water; Water footprint; Direct and indirect water footprints; Water footprint analysis

\section{Introduction}

Many organizations worldwide are recognizing that water is an essential ingredient in their business operations and the lack of access to sufficient water quantities and water pollution are posing a material risk to a growing number of companies [1]. Concern about water is highlighted by a survey of the companies conducted by the World Economic Forum in 2015, which indicated that there will be serious water crises risk over the next 10 years [2].

According to World Business Council for Sustainable Development, water is not only key to the world's stability, prosperity and peace but it is also essential for business to operate. In the next three decades the demand for water will increase by 40 -
$50 \%$ for global food sector, by 50-70\% for municipal and industrial sector and by $85 \%$ for the energy sector. Increasing competition for water demands need immediate action, and radical change in the way that companies manage water [3]. The textile industry touches everyone's lives through clothing, fabrics and other products; however, it has a significant impact on the world's resources. Its production depends heavily on water, from raw materials production to the industrial processing stages. Rising competition for water is already impacting the textile and Equally significant is the situation of workers in the supply chain, where in developing countries working conditions often do not meet minimum human rights and fair labor standards [4]. 
Cotton is the most liked fiber in textile industry. However, it is the biggest culprit of water consumption and water pollution. Despite only occupying $2.4 \%$ of World's cropland, cotton accounts for $24 \%$ of the world's insecticide use and $11 \%$ of pesticides. Toxic chemicals washing into waterways and entering the ecosystems, is becoming a major source of pollution, especially in developing countries [1]. Unsustainable cotton farming has resulted in the loss of Aral Sea in central Asia. In the 1960s, the Aral Sea was the fourthlargest lake in the world. It was an important source of life for the surrounding communities and home to millions of fish. It now covers a mere $10 \%$ of its original area. The local Uzbek communities have suffered the loss of livelihoods and food sources while gaining new health impacts. The dust from the lake is carcinogenic covering most of the villages [5].

It's estimated that around $20 \%$ of industrial water pollution in the world comes from the treatment and dyeing of textiles, and about 8,000 synthetic chemicals are used to turn raw materials into textiles. Each year, textile companies discharge millions of litres of chemically infected water into waterways. It is estimated that a single mill can use 200 litres of fresh water per kilogram fabric during chemical processing operations. So, there is not only highwater consumption, but the chemicals pollute the water causing both environmental damage and spreading diseases throughout developing communities.

In the developing world, where the majority of textile manufacturing takes place, factories and textile mills are located directly along or close by waterways such as rivers and canals. These factories on an average use 1.5 billion cubic meters of fresh water each year. In places like Dhaka in Bangladesh and Tirupur in India the water is so polluted at times, it is not even safe for livestock. Many industries and households that rely on fishing and farming to make a living are now suffering as a result of the lack of freshwater [6]. Another source of water pollution which has been recently identified is the domestic washing of clothes. The wash water is found to contain large number of micro fibers of synthetic garments particularly polyester. These micro fibers from wash water are eventually found to end up in sea endangering aquatic life and eventually entering food system consumed by human being [7].

The present series of articles will highlight how textile and fashion industry along its supply chain is thirsty of water which is posing threat to the depleting sources of water worldwide particularly in developing countries where most of the textile and fashion production activities are concentrated because of cheap labour and less stringent environmental laws. This first introductory part of series highlights the water distribution on earth indicating how very small quantity of fresh water is available for human consumption though almost $71 \%$ area of earth is covered with water. There is also non-equitable distribution of water in different regions and water pollution is posing a serious threat to already depleting water sources. This part of series also highlights the development of water footprint concept, its importance, and assessment of water footprints, strategies for reduction of water footprints and certification and labelling. Subsequent parts of the series will highlight water footprints from fibre to finished product stages.

\section{Water Distributions on Earth}

The surface area of the Earth is $\mathbf{5 1 0}$ million square kilometers. The Earth is a water heavy planet, so, if one breaks its surface area into water and land segments, it would be:

a) Land 149 million $\mathrm{km}^{2}$

b) water 361 million $\mathrm{km}^{2}$ [8]

Following pictorial view depicts how earth is surrounded by oceans (Figure 1).

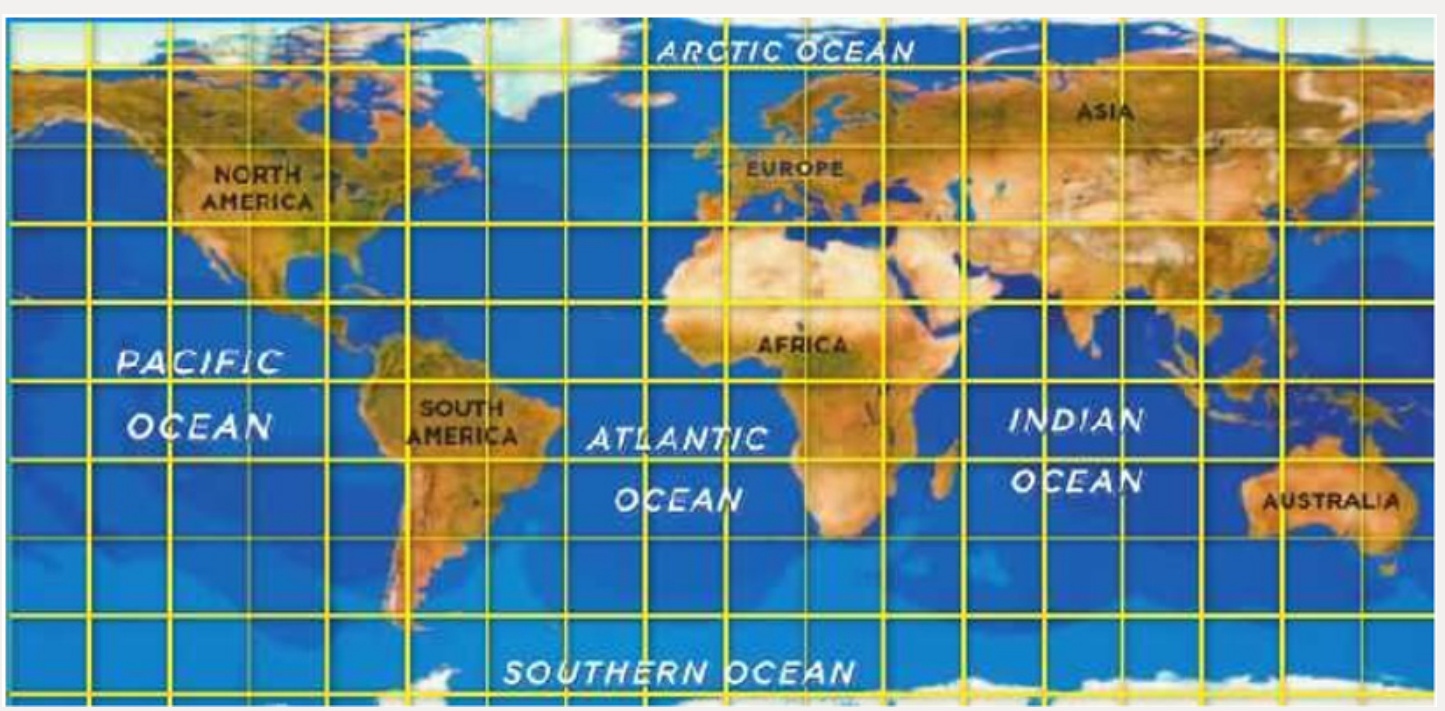

Figure 1: Pictorial view of earth surrounded by water. 
About $71 \%$ area of earth is covered by water and $29 \%$ is the land area. For this reason, earth is also known as blue planet. Water distribution on earth is shown in the form of pie chart in Figure 2 [10]. It can be seen that about $97 \%$ of all water is in the oceans and $3 \%$ exists as fresh water. The middle pie shows the distribution of that three percent of all Earth's fresh water. The majority of fresh water (about 70 percent), is locked up in glaciers and icecaps, mainly in Greenland and Antarctica. This is equivalent to $2 \%$ of total fresh water. This means that $99 \%$ of water available on earth (ocean + ice caps, glaciers) is not usable [10]. The remaining 1\% of fresh water is available in two forms viz: surface water in the form of rivers and lakes and ground water. The distribution of this $1 \%$ of useable water is shown in Figure 3.

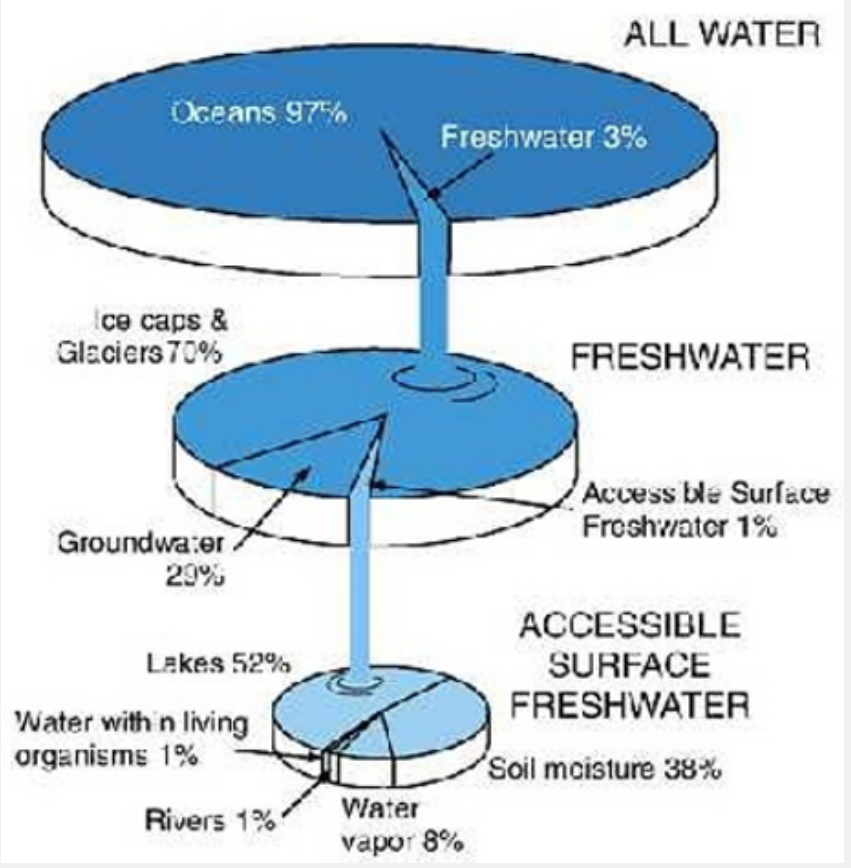

Figure 2: Water distributions on earth [10].

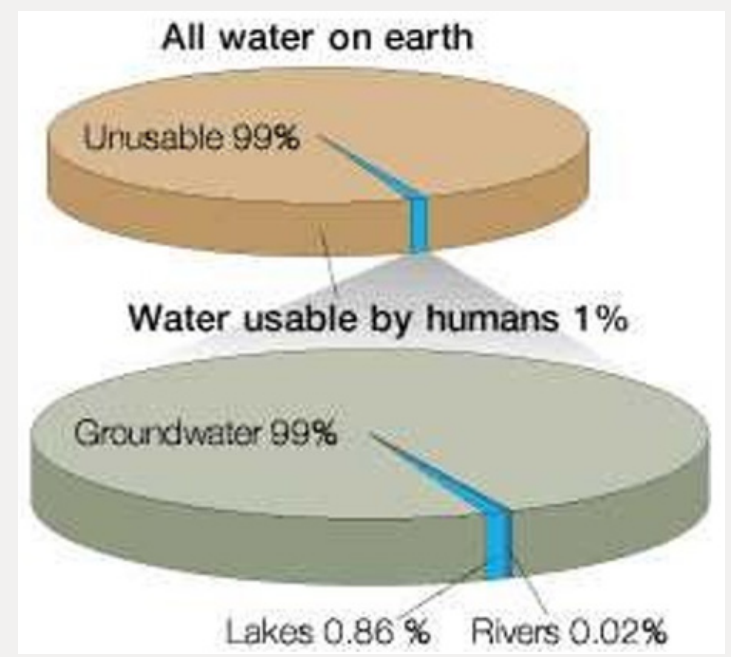

Figure 3: Availability of useable water [11].

It can roughly be estimated that about $99 \%$ of all water (oceans, ice caps, glaciers, saline water other than ocean, and atmospheric vapors) is not available for our uses. Even of the remaining fraction of $1 \%$ which is available for use is present in the form of surface water (rivers and lake 1\% and ground water 99\%) [11].

\section{Estimate of Global Water Distribution}

Table 1 summarizes in terms of percent the distribution of all the water available on earth. It can be seen that the world's total water supply of about 332.5 million cubic miles (1,386 million cubic kilometers) of water, over 96 percent is saline, and of the total 
freshwater, over 68 percent is locked up in ice and glaciers. Another 30 percent of freshwater is in the ground [12]. Thus, surface- water sources (such as rivers and lakes) only constitute about 22,300 cubic miles $(93,100$ cubic kilometers), which is about $1 / 700$ th of one percent of total water, yet rivers are the source of most of the water people use.

Table 1: Quantification of all the water on earth [12].

\begin{tabular}{|c|c|c|c|c|}
\hline Total source & Water Volume in miles3 & Water Volume in kilometers3 & $\%$ of Freshwater & $\%$ of Total Water \\
\hline Oceans, Seas, \& Bays & $321,000,000$ & $1,338,000,000$ & - & 96.5 \\
\hline $\begin{array}{l}\text { Ice caps, Glaciers, \& } \\
\text { Permanent Snow }\end{array}$ & $5,773,000$ & $24,064,000$ & 68.7 & 74 \\
\hline Groundwater & $5,614,000$ & $23,400,000$ & - & 1.7 \\
\hline Fresh & $2,526,000$ & $10,530,000$ & 30.1 & 0.76 \\
\hline Saline & $3,088,000$ & $12,870,000$ & - & 0.94 \\
\hline Soil Moisture & 3,959 & 16,500 & 0.05 & 0.001 \\
\hline $\begin{array}{l}\text { Gound Ice and } \\
\text { Permafrost }\end{array}$ & 71,970 & 300,000 & 0.86 & 0.022 \\
\hline Lakes & 42,320 & 176,400 & - & 0.013 \\
\hline Fresh & 21,830 & 91,000 & 0.26 & 0.007 \\
\hline Saline & 20,490 & 85,400 & - & 0.006 \\
\hline Atmosphere & 3,095 & 12,900 & 0.04 & 0.001 \\
\hline Swamp Water & 2,752 & 11,470 & 0.03 & 0.0008 \\
\hline Rivers & 509 & 2,120 & 0.006 & 0.0002 \\
\hline Biological Water & 269 & 1,120 & 0.003 & 0.0001 \\
\hline Total & $332,500,000$ & $1,386,000,000$ & - & 100 \\
\hline
\end{tabular}

\section{Regional Inequity in Water Distribution}

There are considerable variations in water availability in different parts of world. While some countries are water rich, others are at risk of becoming arid and may in the future be incapable of sustaining their populations. Early in the new millennium, the top five water rich countries were French Guiana, Iceland, Guyana, Suriname, and Congo. At the bottom of the scale were Kuwait, the Gaza Strip, the United Arab Emirates, the Bahamas, and Qatar [13].

Between those extremes a growing number of countries suffer from various forms of water stress, either caused by the drying up of resources, the depletion of the water table, the pollution of rivers and lakes, or, as in Africa, years of drought. Over half the countries of the world have been deemed either "dangerously dry" or "under the poverty line of water availability" [14]. North America is particularly fortunate to be home to the largest source of surface freshwater on Earth, the Great Lakes Basin, containing about 21\% of the world's total supply of fresh water [15]. By contrast, there is a significant part of the world is arid, making up large parts of Australia, Africa, and Asia. The so-called "hot spot" areas that are running short of potable water include Northern China, large areas of Asia and Africa, the Middle East, Australia, the Midwestern United States and sections of South America and Mexico" [16].

India is depleting its groundwater so rapidly that its future food crops and drinking water supplies are threatened [17]. With the world's second largest population, water shortages in India will continue to have a massive impact. Ironically, there is considerable rainfall in many regions of India, but it can be irregular or unpredictable and Indian farmers have been at the mercy of rain [17]. Unusual weather patterns in recent years, have afflicted India with the competing "curses of drought and floods." The escalating problems are blamed on climate change [18].

\section{Climate Change}

In simple term "Climate change is characterized by erratic weather patterns leading to droughts, floods, more frequent and more intense natural disasters and other phenomena" [19]. A volume of information is available on the effects of climate change on environment including water scarcity. The purpose of this paper is not to review the literature but only to mention the opinions of some of the experts on the global effects of climate change on water availability. Some of these opinions are quoted below: Climate change "is going to affect the amount of water that comes in as precipitation [20]. By one estimate, just two degrees rise in temperature can adversely impact water accessibility for 3 billion people [21].

José Graziano da Silva, Director-General of the FAO, commented that "more extreme and frequent droughts resulting from climate change are having devastating food security impacts, especially in the most vulnerable regions of the world" [22]. While rainfall has for centuries replenished the freshwater supply, given the current levels of usage, precipitation will not suffice to meet the need and 
demand. "Precipitation is a key source of water supply ... but this will only be useful if it can be caught and utilised effectively" [23]. Peter Gleick explained the connection between climate change and the hydrological cycle: "Global climate change is going to have very dramatic impacts on water resources because the hydrologic cycle is such a fundamental part of the climate cycle" [24].

It has correctly been said that "water will be the vehicle through which climate change is felt" [25]. Jouni Paavola of the Centre for Social and Economic Research on the Global Environment at the University of East Anglia commented that "climate change, water and poverty are intimately intertwined in the developing world because climate change will manifest itself primarily through variation in the availability of water" [26]. According to UNO, the effects of water scarcity on humanity are quite frightening It is estimated that:

a) Presently around 700 million people in 43 countries suffer from water scarcity.

b) By 2025, 1.8 billion people living in countries or regions with absolute water scarcity and two- thirds of world's population could be living under water stressed conditions.

c) With the existing climate change scenario, almost half the world's population will be living in areas of high stress by 2030 .

d) Sub-Saharan Africa has the largest number of waterstressed countries of any region [27].

In spite of all the scientific controversies surrounding the issue of climate change and despite the years-long political wrangling that has delayed implementation of the Convention on Climate Change, Nature seems to be taking matters into its own hands to show humanity that it can no longer tolerate so much abuse. The result is that natural disasters are becoming commonplace. Speak to any senior citizen and one hears about the fact that in the past such disasters were less frequent and not as terrifying as they appear to be now. Such evidence may be anecdotal but there do seem to be great extremes of climate causing havoc in many parts of the world. Textile and fashion industry are the thirstiest for water as it is one of the largest water consumers from fibre production to finished product.

The above gloomy picture of water scarcity is good enough to caution the textile and fashion industry to take appropriate measures to use the water resources sustainably and make all efforts to save water at every stage of supply chain. The present series of articles will highlight the water footprints of textile and fashion industry from fibre to finished products.

\section{Virtual Water and Water Footprint Concepts}

\section{Virtual Water}

Professor John Allen from King's College London was the first to introduce the concept of virtual water in 1994 [28]. It was based upon analyses by Israeli water experts who found that it seemed to make more sense for their arid country to import water-intensive goods than to cultivate them themselves. Allen introduced the virtual water concept, to throw light on how Middle Eastern countries' water requirements have exceeded available resources since 1970. Trying to explain why there no war over water has been when many economies in the Middle East region have only half the water they need, Allan argued that economic systems solved the water supply problem for the region, supplying water via trade. In other words, water scarcity in these countries was being managed by importing virtual water in the form of agricultural products from the international market [29].

Allan stated: "The water is said to be virtual" because; the final product contains only a small fraction of water compared to the total volume of water actually used for its production. This means that once the agriculture product is grown, the real water used to grow it is no longer actually present in the product [30]. Virtual water can be defined as the water that is required for manufacturing a product or for rendering a service. Virtual water also contains the actual amount of water that exists in certain product as moisture.

In everyday language, 'virtual' is often misinterpreted as 'fictitious' or as the opposite to 'real'. As used here, however, 'virtual' is a notional quality that exists in its effects rather than in a physical sense.

The concept of 'embedded water' (which was coined before 1994) has not managed to gain acceptance [31].

It is a revolutionary concept because it describes something never conceptualized before. Thus, virtual water helps to understand how virtual water flows between countries or regions in the form of international trade [29]. The global trade in goods has allowed countries with limited water resources to rely on the water resources in other countries to meet the needs of their inhabitants. As food and other products are traded internationally, their water footprint follows them in the form of virtual water [32].

Two different definitions have been suggested in the attempt to provide a more detailed description of virtual water [33]: According to the first definition, virtual water denotes the water that is actually required for manufacturing a certain quantity of a product at the respective site of production (production-site definition) According to the second definition, it is defined as the water that would be necessary for manufacturing the same amount of the same product at the place where the product is eventually needed (consumptionsite definition)[34]. The First definition refers to the producer's perspective, while the second refers to the consumer perspective.

The amount of water needed for the production of agricultural goods as well as industrial goods may considerably depend on the production site. For example, let us assume that the amount of 
water required for manufacturing the same amount of the same product is three times higher in country A than in country B. In this case, the export of the same amount of this product from $A$ to $B$ would involve a threefold transfer of virtual water compared to an export from B to A. Consequently, product transfer from A to B implies that $\mathrm{A}$ loses three times the amount of virtual water that $\mathrm{B}$ would save if it produced the same amount of the same product in its own country [31].

\section{Importance of Virtual Water Concept}

As nations work toward securing food, water, energy and other essential inputs for people's wellbeing, livelihoods and the country's economic development, most countries rely on imports as well as exports of goods and services. A country may aim to be self-sufficient by relying primarily on goods that can be produced within its borders. Or a country may choose to reduce the burden on the natural resources within its borders by importing water intensive products from other countries.

For water-scarce countries it can sometimes be attractive to import virtual water (through import of water-intensive products), thus relieving the pressure on the domestic water resources. This happens, for example, in Mediterranean countries, the Middle East and Mexico. It results from protection of their domestic water resources, land availability and land uses. Countries can both import and export virtual water through their international trade relations. Globally, the major gross virtual water exporters are USA, China, India, Brazil, Argentina, Canada, Australia, Indonesia, France and Germany. The biggest net virtual water importers are North Africa and the Middle East, Mexico, Europe, Japan and South Korea.

There are many examples of water-poor countries that save their domestic water resources by importing water-intensive goods. Mexico, for example, imports maize and, in doing so, it saves 12 billion cubic meters per year of its national water resources. This is the volume of water that it would need domestically if it had to produce the imported maize within the country [32].

\section{Merits of Virtual Water}

Virtual water has major impacts on global trade policy and research, especially in water-scarce regions, and has redefined discourse in water policy and management. By explaining how and why nations such as the US, Argentina and Brazil 'export' billions of litres of water each year, while others like Japan, Egypt and Italy 'import' billions of litres of water each year.

The virtual water concept has opened the door to more productive water use. National, regional and global water and food security can be enhanced when water intensive commodities are traded from places where they are economically viable to produce to places where they are not. While studying water scarcity in the Middle East, Professor Allan developed the theory of using virtual water import, via food, as an alternative water "source" to reduce pressure on the scarcely available domestic water resources there and in other water-short regions [35].

\section{Limitations of Virtual Water [36]}

Key shortcomings of virtual water concept are:

a) It relies on an assumption that all sources of water, whether in the form of rainfall or provided through an irrigation system, are of equal value.

b) It implicitly assumes that water that would be released by reducing a high-water use activity would necessarily be available for use in a less water-intensive activity.

c) It fails as an indicator of environmental harm and does not provide any indication of whether water resources are being used within sustainable extraction limits. The use of virtual water estimates therefore offer no guidance for policy makers seeking to ensure that environmental objectives are being met.

\section{Water Footprint Concept}

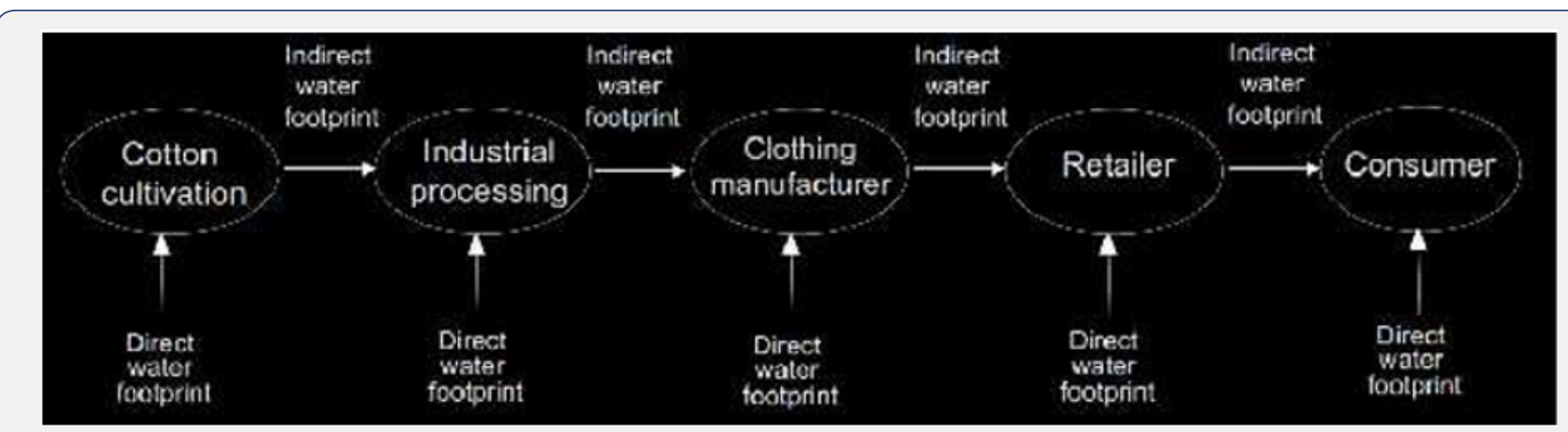

Figure 4: Supply chain of cotton product [38]. 
Building upon the concept of virtual water, the concept of water footprint was coined in 2002, by Arjen Hoekstra, Professor in water management at the University of Twente, Netherlands, and co-founder and scientific director of the Water Footprint Network, whilst working at the UNESCO- IHE Institute for Water Education, to measure the amount of water consumed and polluted to produce goods and services along their full supply chain [37].The water footprint along the supply chain can be illustrated by taking an example of the supply chain of product produced from cotton as shown in Figure 4.

\section{Supply Chain of Cotton Product}

As shown in Figure 4 the water footprint is an indicator of freshwater use that looks not only at direct water use of a consumer or producer, but also at the indirect water use during the supply chain. The water footprint of a product is the volume of direct and indirect freshwater used to produce the product, measured over the full supply chain [39].

It should be understood that the term 'water consumption' used in the concept of water footprint means the evaporation of water from the surface or evapotranspiration of water from plants and the water present in the product itself. This is based on the fact that the agricultural or industrial products do not consume water during their production except that present in the product itself as natural moisture content. Percolation/run-off of water during production to ground which results into ground water recharging is excluded from the water consumption [40]. The two components of water footprint i.e direct water and indirect water use is further illustrated in Figure 5.

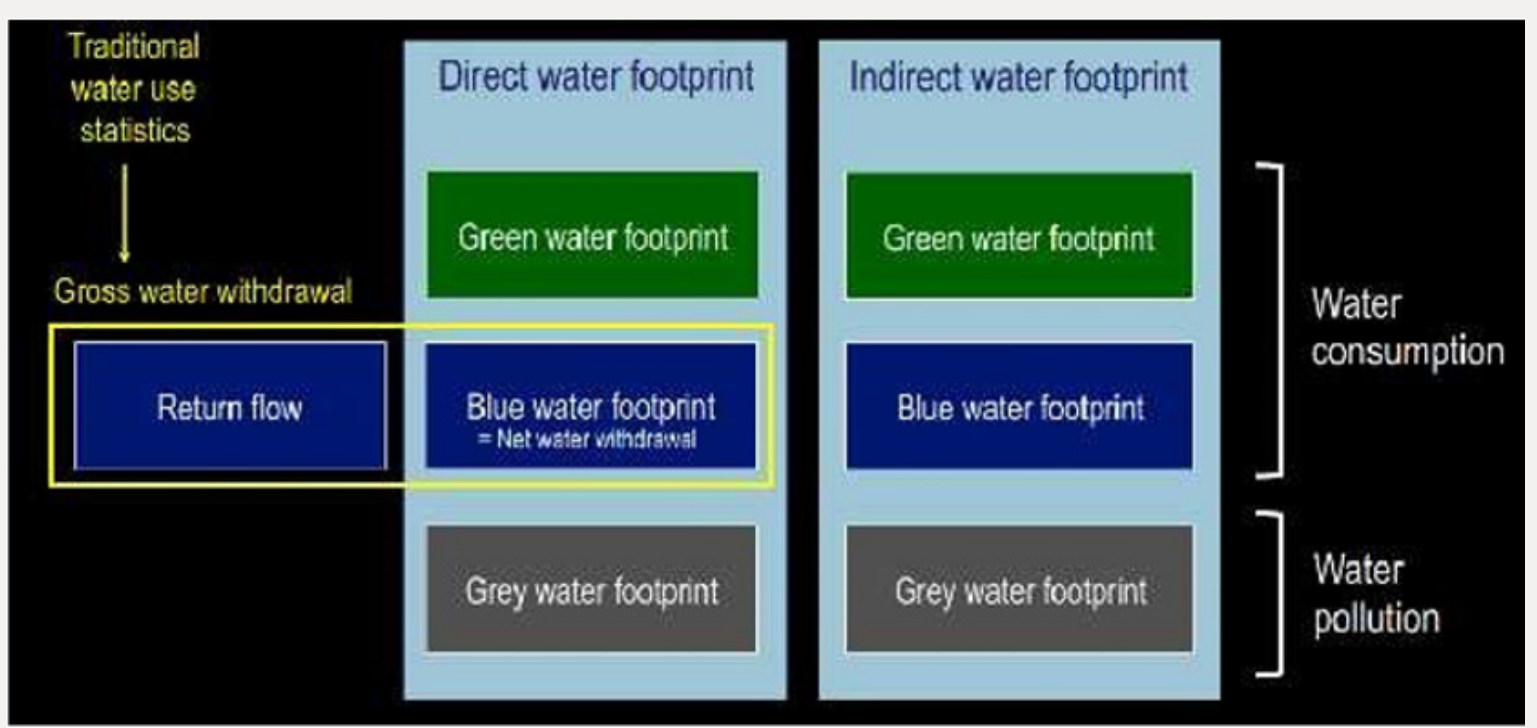

Figure 5: Schematic representations of the direct and indirect components of a water footprint [38].

It shows that the non-consumptive part of water withdrawals (the return flow) is not part of the water footprint. It also shows that, contrary to the measure of 'water withdrawal', the 'water footprint' includes green and grey water and the indirect water-use components.

Hoekstra [41] differentiates between the footprint of a consumer and a business as follows:

a) The water footprint of a consumer $=\sum$ direct water use (e.g. drinking) + indirect water use (production and services)

b) The water footprint of a business $=\sum$ direct water use (e.g. production) + indirect water use (supply chain).

The water footprint thus offers a better and wider perspective on how a consumer or producer relates to the use of freshwater systems. It is a volumetric measure of water consumption and pollution. It is not a measure of the severity of the local environmental impact of water consumption and pollution [42]. Earlier water-footprint studies were limited to the quantification of resource use, i.e. the use of groundwater, surface water and soil water $[33,37,43]$. Subsequently the water footprint concept was further extended through quantifying the impacts of pollution as well. As shown in Figure 6.

Water quality has been decided by quantifying the dilution water volumes [44] required to dilute waste flows to such an extent that the quantity of pollutants remain below agreed water quality standards [45]. The most elaborate publications on how to estimate water footprints are 2004 report on the Water footprint of nations from UNESCO-IHE [46], the 2008 book Globalization of Water [47], and the 2011 manual the water footprint assessment manual: Setting the global standard [42]. Cooperation between global leading institutions in the field has led to the establishment of the Water Footprint Network in 2008. 


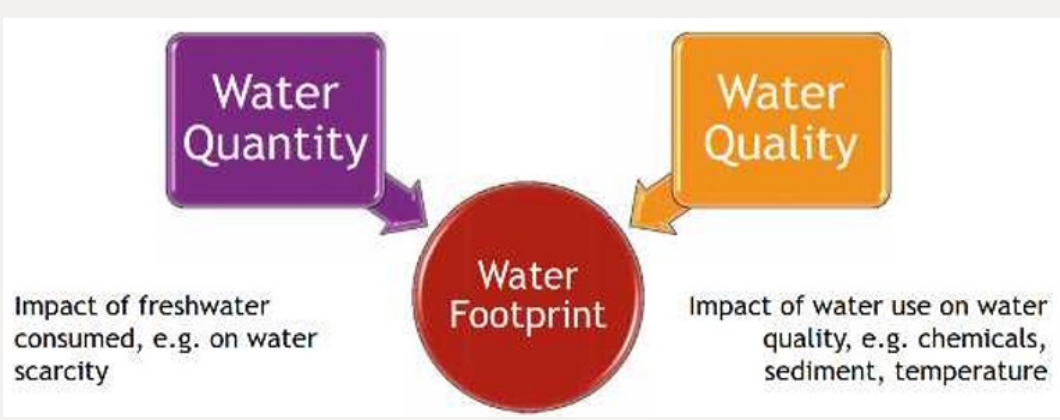

Figure 6: Water footprint concept extended to water quality [44].

\section{Water Footprint of a Nation}

The water footprint of a nation is defined as the total amount of water that is used to produce the goods and services consumed by the inhabitants of the nation. The water footprint of a nation has two components. The internal water footprint defined as the water use within the country in so far it is used to produce goods and services consumed by the national population. The external water footprint of a country is defined as the annual volume of water resources used in other countries to produce goods and services imported into and consumed in the country considered $[48,49]$. The water footprint of a nation is illustrated by following two Figures $7 \& 8$.

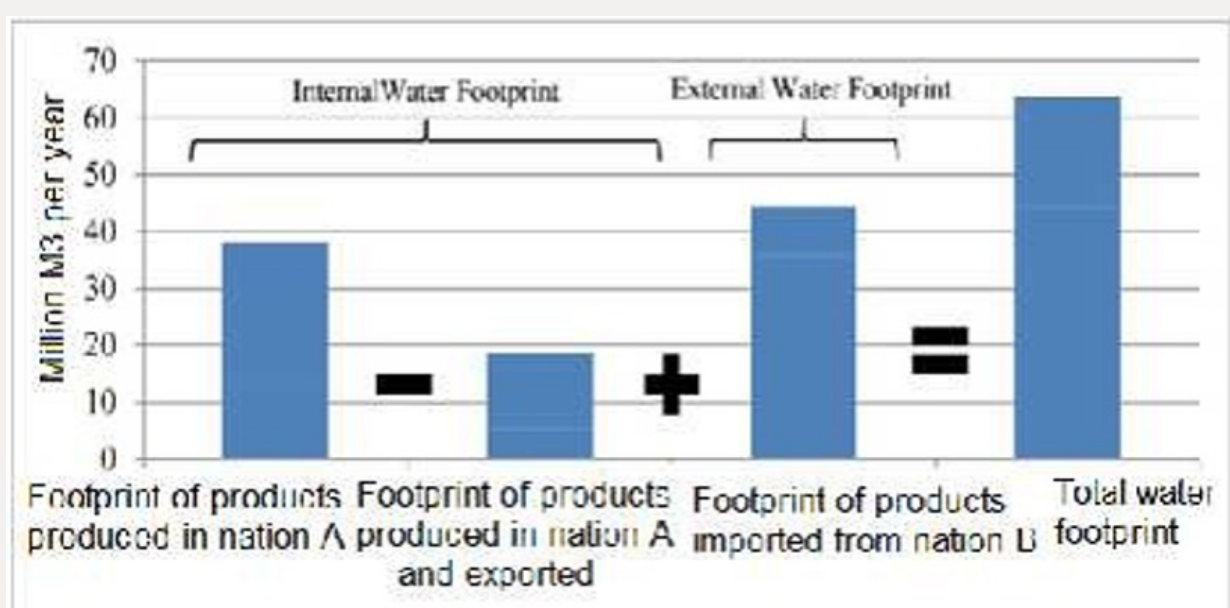

Figure 7: Water footprint of a nation.

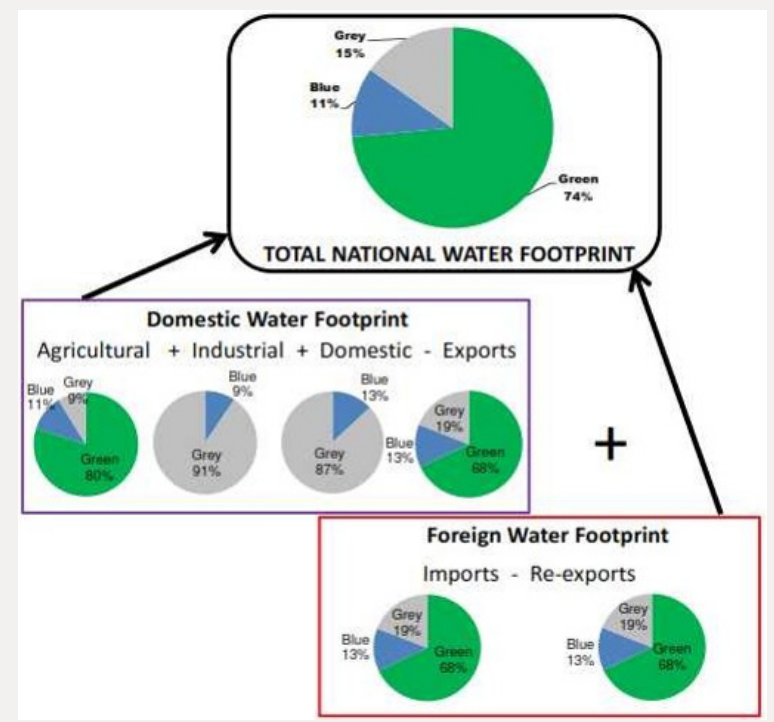

Figure 8: Composition of national water foot print [39]. 
The national water footprint is composed of domestic goods and services plus imports (incoming water) minus exports (outgoing water). Each of these has green/blue/grey components. Data are from Hoekstra \& Mekonnen (and show global averages to illustrate differences in water composition [50]. It will also be interesting to know the Global average numbers and composition of all national water footprints, internal and external as shown in Figure 9.

\section{Global Water Footprint by sector}

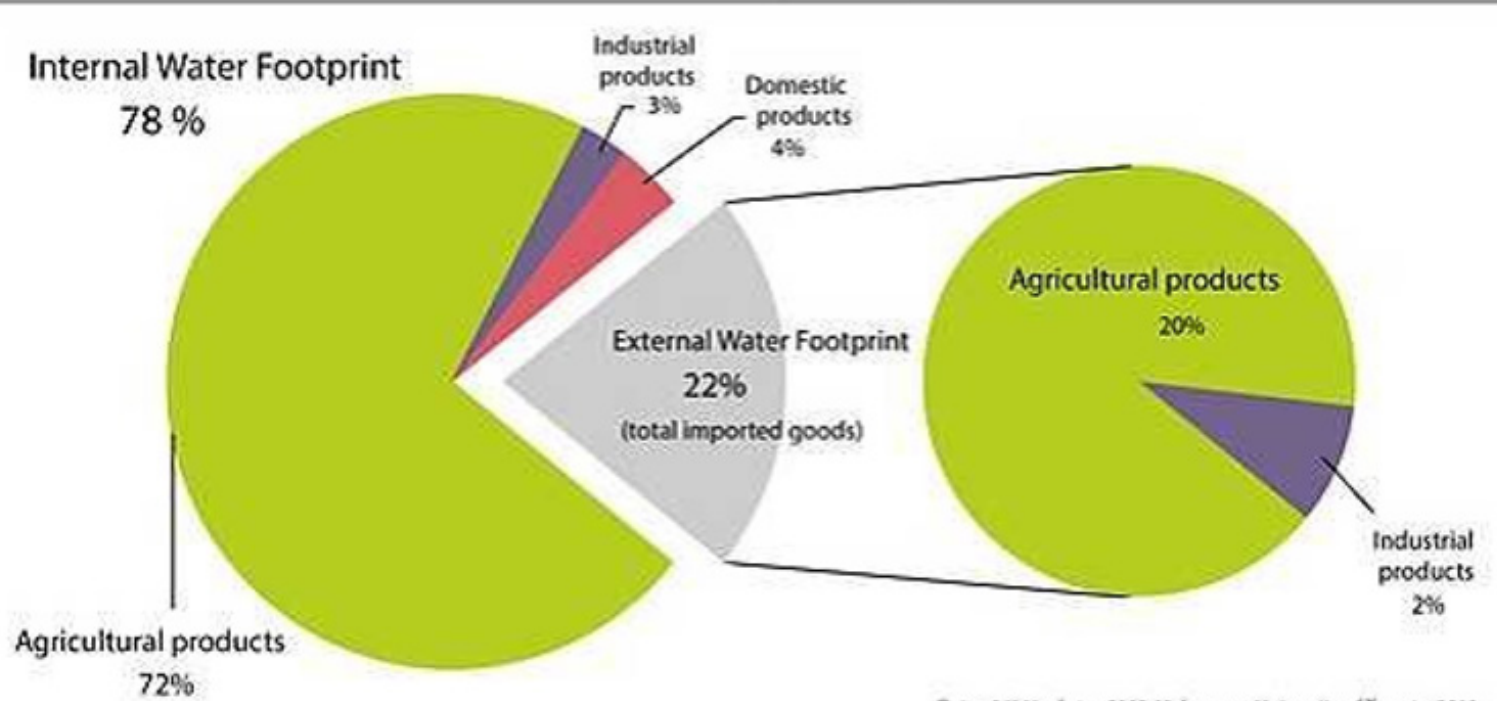

Dutx: AX. Hoekistex, MM M. Nehornen, University of Twente, 2011

Figure 9: Global average numbers and composition of all national water footprints, internal and external [51].

The external part of a nation's water footprint varies strongly from country to country. Some African nations, such as Sudan, Mali, Nigeria, Ethiopia, Malawi and Chad have hardly any external water footprint, simply because they have little import. Some European countries on the other hand, e.g. Italy, Germany, the UK and the Netherlands have external water footprints that constitute $50-80 \%$ of their total water footprint. The agricultural products that on average contribute most to the external water footprints of nations are: bovine meat, soybean, wheat, cocoa, rice, cotton and maize [51].

\section{Components or Colors of WF}

While determining the total water footprint, the consumption of rain water, ground water, surface water along with extent of water pollution is taken into account. These are considered as components of water footprint and are represented by Green water (Rain water or precipitation), Blue water (ground and surface water) and Grey water (volume of fresh water required to dilute the pollutants). The total water footprint is the summation of these three colors of water. In case of national water footprint, the import and export of virtual water is also taken into account [52].

\section{Green Water Footprint}

Green water resources have been defined as the infiltrated rainfall in the unsaturated soil layer [53]. The green water footprint therefore refers to the precipitation consumed by a crop through evaporation from soil (surface evaporation) and evapotranspiration from plants and moisture stored in the soil (also known as effective or productive precipitation) [54]. Green water is particularly relevant for agricultural, horticultural and forestry products. In general, the utilization of "green" water does not apply to industrially or commercially manufactured products and services [47].

\section{Blue water footprint}

Is water that has been sourced from surface or groundwater sources. Irrigated agriculture, industry and domestic water use can each have a blue water footprint. The share of "blue" water contained in these products is defined as the share of the utilised water that is released into the atmosphere as a consequence of evaporation or sublimation and evapotranspiration (in case of agriculture products) and since it cannot be expected to return to the region considered, it may be regarded as consumed. The same applies to service provisions and the water used for domestic purposes. The term blue water consumption is different than blue water withdrawal. A comprehensive definition of the blue water footprint is that it includes all irrigation water and any direct water use in industry or in households, minus return of water in the ground [55]. The green and blue water footprint in relation to water balance of catchment area is shown in Figure 10. 


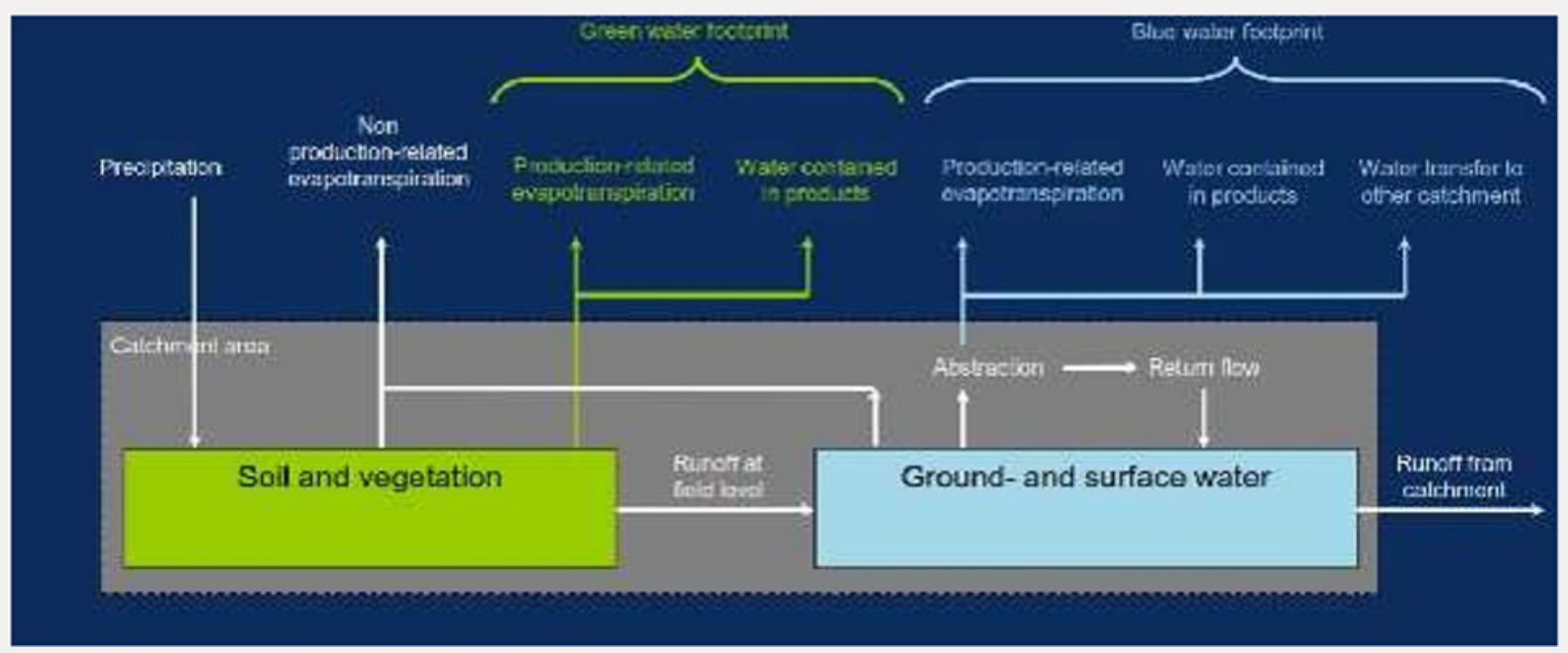

Figure 10: Green and Blue water footprint in relation to water balance of catchment area [48].

For understanding freshwater appropriation by humans in relation to the hydrological cycle, one can consider a river basin. Other terms for 'river basin' often used are 'catchment area', 'drainage basin', 'drainage area' and 'watershed'. The total annual water availability in a catchment area is given by the annual volume of precipitation. The total annual precipitation flow will leave the basin again, partly through evapotranspiration and partly through run-off from the catchment. Both the evaporative flow and the run-off can be appropriated by humans. The green water footprint refers to the human use of the evaporative flow from the land surface, mostly for growing crops or production forest. The blue water footprint refers to the consumptive use of the run-off flow, in other words, the abstraction of run-off from the catchment in so far as it does not return to the catchment in the form of return flow [42].

\section{Grey Water Footprint}

The grey component of a water footprint is defined as the volume of freshwater required in receiving water bodies for the assimilation of any pollutant resulting from production so that acceptable water quality standards are met [54]. Thus, the grey water footprint is an estimated measure of the potential water pollution caused by the production of agriculture and non- agriculture products and supply chain. The grey water footprint considers point- source pollution discharged to a freshwater resource directly through a pipe or indirectly through runoff or leaching from the soil, impervious surfaces, or other diffuse sources [52].

In case of products other than agriculture, the dilution volume is determined in relation to the concentration of contaminant which needs highest volume of water to bring the contaminant concentration to the acceptable level [31]. Whereas in case of agriculture runoff, the contaminant concentration is generally calculated by assuming that $10 \%$ of all nitrogen fertilizer applied to a crop is lost via leaching and taking the average nitrogen application rate by crop in the country being assessed; the assumed fraction of nitrogen leachate is then divided by the maximum acceptable concentration of nitrogen in the receiving water body.

The consideration of grey water is relatively new in water footprint and was not included in earlier water footprint studies, such as Chapagain and Hoekstra [43] it was introduced by Chapagain et al. [56] using the term "dilution water" which later evolved into the concept of grey water [56]. By including all three components, the water footprint aspires to encompass all kinds of direct and indirect consumptive (blue and green) water use and pollution assimilation (through grey water estimates).

In case of agriculture products, Blue and green water footprints are calculated by multiplying the modelled volume of blue and green water use (m3/output unit e.g. m3/ton). In this way, any rainfall used in situ by the crop (green water) is distinguished within the water footprint of a product, as well as the volume of irrigation (blue) water assumed to be applied to each crop. The grey water footprint is an estimate of the amount of water needed to assimilate nutrients in agriculture water runoff to ground and surface water.

\section{Difference between Virtual Water and Water Footprint}

The water footprint refers to the water used to make a product. In this context there is no difference between virtual water and water footprint. However, the water footprint is a multidimensional indicator, not only referring to a water volume used, but also making explicit where the water footprint is located, what source of water is used, and when the water is used. Thus, the most typical feature of water footprint is the importance of specifying space and time. This is necessary because the availability of water highly varies in space (regions) and time, so that water appropriation should always be considered in its local context. 
Other applications of the water footprint are for example identifying hotspot areas of the water footprints of certain products, consumer groups or businesses, and formulating response strategies to mitigate water footprint impacts. This additional information is crucial in order to assess the impacts of the water footprint of a product. The term virtual water is used mainly in case of international trade for importing or exporting the product. e.g. when an agriculture or commodity product is imported this means that along with the imported product one is importing virtual water which was required to produce the product in the country of origin and vice- versa for the export of the product [57].

Velázquez et al. [58] expressed that virtual water is defined as a physical indicator of the amount of water needed to produce goods and services, and water footprint as the amount of water needed to produce the goods and services that will be consumed by a country or an individual. Therefore, virtual water is consolidated as a production perspective indicator while water footprint is a consumption perspective indicator. This difference between virtual water and water footprint is interesting since it allows us to profit from two indicators defined from different perspectives and capable of identifying the subjects who are responsible for water consumption, whether producers or consumers. Despite the evident difference between the two concepts there could be a growing confusion surrounding both concepts. They have often been used as synonyms and, thus, have partly lost the potential that is associated to the difference between them. But the relevance of these two concepts is so significant that both public administrations and big corporations (Danone, Nike, Levi-Strauss, Coca-Cola, etc.) have decided to explore the possibilities of including them to support various alternatives in their decision- making processes [59].

\section{Criticism of the Water Footprint Concept}

The most important criticism of water footprint is its weak relationship between the footprint's indicator and the footprint's environmental impact. The blue and green components in particular measure resource use and not environmental impact. A crop may have a large water footprint but little environmental impact, as it is growing in a water-abundant environment, whereas a crop with a lower water footprint may have a significant environmental impact by using scarce blue water supplies. To compare the environmental friendliness of products, it is of little value to compare their water footprint indicators. This especially applies to the green water component, usually the major component of a water footprint indicator.

Evaporation of rainwater and evapotranspiration from plants are natural processes of the hydrological cycle and evapotranspiration from natural vegetation may even exceed evapotranspiration from crops. Therefore, correcting for the evapotranspiration from natural vegetation, seems to be more appropriate if environmental impacts are considered [60]. By taking green water into account in a water footprint assessment to detect hot spots is a questionable method. In this respect, the Water Footprint Network's Assessment manual states that the green water footprint in relation to sustainability needs further research and it recommends excluding a quantitative assessment of green water scarcity from practical policy- making for the time being [42]. Nevertheless, considering the green water content of water-intensive commodities can be useful in the context of resource use and international trade. In such a case, green water is looked at as a scarce resource and not as a source of environmental damage [50].

\section{Grey Water}

There is no clarity about grey water measurements. Green water in case of agriculture and blue water can be quantified but it is problematic to add the share of grey water while determining the total water footprint indicator because part of grey water can be brought into system by recycling after effluent treatment. In fact, in the zero-discharge principle almost $80-90 \%$ of water is recycled except which is lost in the form of sludge and evaporation. Also, in many countries grey water is used in agriculture [39].

Berger and Finkbeiner [61] criticized the attempt to combine water quantity and quality aspects in one single indicator and the way water pollution is converted into volumes of grey water. Also, the lack of reliable data to actually calculate water footprint indicators is a source of criticism. Water quality is less elaborated than water quantity in the water footprint concept and databases. The immense variety of pollutants, their use and behaviour make it a laborious task to include water quality aspects in water footprint assessments [62].

Finally, it is argued that the full water footprint assessment provides nothing that is not already provided by existing water resource management and supply chain assessment tools $[63,64]$. The water footprint concept would be one of sticking new labels on old concepts. However, one may also argue that there is added value in bringing together existing tools for water resource management and supply chain management to form one complete approach, because it connects two different worlds of researchers and users, which may be fruitful for new insights.

\section{Development in Water Footprint Methodology}

According to the Water Footprint Assessment Manual of the Water Footprint Network [42] the goal of assessing water footprints is to analyze how human consumption relates to the issues of water scarcity and pollution, and to see how consumption can become more sustainable from a water perspective. Human consumption is linked to freshwater use and the emission of pollutants to water along production and supply chains of consumer products and 
their use. The tool to analyze water footprints is what is called a 'water footprint assessment'.

During the first few years of the development of the water footprint concept (2002-2008), the focus was on calculating the footprint's total size. This resulted, for instance, in the notion that one apple costs 125 litres of water and one cotton shirt about 2500 litres [40]. These large volumes of water connected to products captured the imagination of many, and NGOs have used them to raise awareness among consumers, producers and governments about the size and global dimensions of water use related to consumer products. The location of the footprint components and their geographic context received little attention. From 2008 onwards, more attention has been given to the location of footprints and their geographic context. The water footprint theory has evolved from an accounting method for calculating an indicator to a methodology to perform water footprint assessments in which the accounting phase is followed by an impact or sustainability assessment. An early example of such an assessment is the study by Van Oel et al. [65] that relates the water footprint indicators for Dutch consumption to locations with water scarcity. This development has also directed the research by the Water footprint network towards the mapping of global water scarcity and pollution $[66,67]$.

It should be noted that the developments around the water footprint concept have resulted in some confusion about the footprint's exact meaning. Originally, the water footprint was synonymous with its total volume, resulting in the well-known water volumes assigned to products. However, currently, and in the context of a water footprint sustainability assessment, it is considered a geographically explicit indicator, representing not only water-use volumes and pollution, but also showing the locations of the footprint. This is logical, as a water footprint sustainability assessment focuses on the water footprint components in different catchments and sub-catchments, and not on the total size of the water footprint. Confusion about the definition of the water footprint also has been created by various Water footprint network publications and in particular by the assessment manual, which uses both definitions side by side.

\section{Water Footprint Assessment}

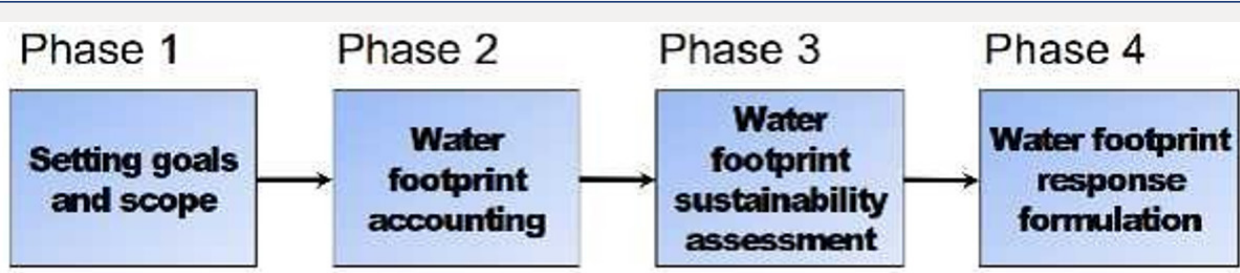

Figure 11: Four distinct phases in water footprint assessment [68].

A full water footprint assessment as described in the Water Footprint Network manual consists of four phases as shown in Figure 11 Studies on virtual water trade and studies carried out to estimate the water footprint indicator for products only; typically consist of the first two phases. When the focus is on the impacts related to the water footprint, the assessment will comprise the first three or all four phases [40].

\section{Setting Goals and Scope}

A water footprint study can be undertaken by nation, river basin authority and business organization for many different reasons. For example, a national government may be interested in knowing its dependency on foreign water resources or it may be interested to know the sustainability of water use in the areas where waterintensive import products originate. A river basin authority may be interested to know whether the aggregated water footprint of human activities within the basin violates environmental flow requirements or water quality standards at any time. The river basin authority may also want to know to what extent scarce water resources in the basin are allocated to low-value export crops. A company may be interested to know its dependence on scarce water resources in its supply chain or how it can contribute to lower the impacts on water systems throughout its supply chain and within its own operations [40].

\section{Water Footprint Accounting}

The main goal of the accounting phase is to keep record of green, blue and grey water volumes associated with the production processes and the supply chain till the product reaches to the consumers. These data are used to calculate the aggregated water footprint indicator by adding up all recorded water volumes. They can also be used to calculate water footprint components such as the green, blue and grey water footprint components, or the imported 'virtual' water from various countries as components of the water footprint indicator for national consumption. When calculated for a particular product while ignoring product use, the water footprint indicator is also referred to as the 'virtual' water content of the product. Depending on the type of study, the water footprint accounting phase could also be the basis for a sustainability assessment [42]. 


\section{Water Footprint Sustainability Assessment}

It may be carried out from the point of view of
a) Water sustainability
b) Social or human sustainability
c) Economic sustainability

\section{Water Sustainability}

The main goal of a water footprint sustainability assessment is to trace processes along the production and supply chains or those associated with product use, which are located in unsustainable 'hot spot' areas. A hot spot is a location where production process uses water from overexploited water resources, pollutes water above water quality standards or where water allocation and use are considered unfair or economically inefficient. To trace hot spots, the major water footprint components are viewed in their geographic context, preferably at catchment or sub- catchment level.

The catchment areas concerned are assessed on sustainable water use, taking into account all major claims on water resources and emissions to water within the catchment or sub- catchment areas. If the required data are not available, separate catchment studies should be done. A catchment's possible environmental unsustainability is determined by the degree of blue and green water scarcity and the water pollution level, taking into account temporal (time related) aspects, as problems of water scarcity and pollution may be concentrated around certain periods of the year.

\section{Social Unsustainability}

Social unsustainability is considered to the case when basic human needs are not being met for all people in the catchment or sub- catchment area or when basic rules of fairness are not being applied for water- related issues.

\section{Economic Unsustainability}

Economic unsustainability would refer to a situation where water is neither allocated nor used in an economically efficient way. The temporal (time related) aspect of water scarcity is becoming more important as climate change may influence precipitation patterns as well as total amounts.

Theory, methods and tools of a full water footprint assessment as well as its practical application are still developing and in an experimental phase [42].

\section{Response Formulation}

To support response formulation with respect to the detected hot spots and water-inefficient processes, the Water footprint network manual gives an overview of response options for various actors, including consumers, companies, farmers, investors and governments. On a global scale, for instance, water-intensive production processes would best be located in water-abundant areas, and optimal use could be made of rain-fed agriculture to release the pressure on water-scarce areas. On a local scale, one could think of technical measures to reduce water use and pollution, and optimization of water allocation according to fairness or economic criteria.

\section{Assessment Tools}

To reduce the impacts of water footprints through sustainable water management, the first step would be to assess current water management practices, associated impacts and risks, and response options. To that end, a number of tools have been developed from different perspectives such as sustainable corporate water management, sustainable water management in production and supply chains, and sustainable management of drainage basins. Below, the most relevant tools are identified:

\section{Water Footprint Network}

The website of the Water Footprint Network presents several tools and many publications; for instance, The Water Footprint Assessment Manual, calculators for individual water footprints, national water footprint case studies and a database. The methodology described in the manual can be applied to various types of water footprint assessments, including those on product and company level. The Water Stat database contains data from various studies on water footprints, virtual water, water scarcity and pollution. The Water Footprint Assessment Tool is free online web application assisting users in water footprint quantification, sustainability assessment and response formulation.

\section{Eureaka}

Under its $7^{\text {th }}$ Framework Programme for Research and Technological Development, the EU has funded the One Planet Economy Network project (OPEN:EU). This work resulted in the free to use Internet tool EUREAKA, providing integrated ecological, carbon and water footprint data $[69,70]$. The tool models the flow of goods and services between 45 countries and regions, covering the global economy for 57 individual sectors. The sectors cover a range from agricultural and manufacturing industries to transport, recreational, health and financial services.

\section{Global Water Tool}

The Global Water Tool (GWT), launched in 2007, is a free to use tool from the World Business Council for Sustainable Development (WBCSD) for companies operating in multiple countries to map their water use and assess risks for their global operations and production and supply chains [71]. It does not provide specific guidance on local situations that require more in-depth systematic 
analysis. The tool was developed under the leadership of WBCSD member and global engineering company CH2M HILL. An advisory board of 21 other global companies provided guidance in pilot testing. Expertise was provided by The Nature Conservancy and the Global Reporting Initiative. More than 300 corporations have used the tool which is regularly updated with improved data sets and functionalities.

\section{Local Water Tool}

The Local Water Tool (LWT), launched in March 2012, is a free to use tool from the Global Environmental Management Initiative (GEMI) that will help companies conduct systematic assessments of their relationship to water in order to create sitespecific sustainable water management strategies [72,73]. GEMI is a non-profit organization of 26 companies dedicated to fostering environmental, health and safety and environmental sustainability. The development of the tool was carried out in cooperation with the WBCSD to link the tool to the Global Water Tool. It is also supported by an additional number of participants like AkzoNobel and Shell.

\section{Aqua Gauge}

The Ceres Aqua Gauge is a free to use tool that allows companies in the management of water risks [74]. Production, supply chains as well as the impacts of product use on water are considered. Ceres is a US-based coalition of investors, environmental groups, and other public organisations working with companies to address sustainability challenges, such as climate change and water scarcity. The tool was developed by Ceres in collaboration with the World Business Council for Sustainable Development (WBCSD), Irbaris, and the IRRC Institute.Input was provided by representatives from over 50 financial institutions, companies and NGOs, among others are Robeco Asset Management, WWF and The Nature Conservancy.

\section{Water Risk Filter}

The Water Risk Filter is an online application hosted by WWF which is designed to help companies and investors to assess water risks and give guidance on how to respond to such risks [75]. The application aims to cover all relevant aspects of water risks: physical risks (water scarcity, water pollution, ecosystem threats, dependency on hydropower) including those in the production and supply chain, regulatory risks and reputational risks. These risks comprise those that are basin related and company- related.

Risk levels are determined according the scores on a set of indicators multiplied by a corresponding weighting. The scores come from a facility-specific questionnaire or are derived from a number of global data sources, including blue water scarcity and water footprint data from the Water Footprint Network.

The application has been developed for WWF in collaboration with DEG KWF Bankengruppe.

\section{Corporate Water Gauge}

The Corporate Water Gauge is a tool of the Centre for Sustainable Organizations (CSO) providing an indicator for measuring the ecological sustainability of an organization's water use, using a watershed-centric approach [76]. Supply chain aspects are not considered. The tool is not available for free. Licences are granted to clients who engage CSO to either provide related training or assist with at least one application at a site of their choosing.

\section{Aqueduct}

The World Resources Institute (WRI) is developing the Aqueduct Water Risk Atlas from which a first version is now available for free [77,78]. At the heart of Aqueduct is a global database of water risk information that will enable companies, investors, governments and others to create detailed water risk maps. An Aqueduct Alliance, including the Netherlands Ministry of Foreign Affairs, supports the project financially and expert advisors from companies, government agencies, NGOs and academia participate in Aqueduct Alliance Working Groups.

\section{GWP Toolbox}

The toolbox developed by the Global Water Partnership is a free and open database to support integrated water resource management with a library of background papers, policy briefs, technical briefs and perspective papers as well as huge sections of case studies and references [79]. The toolbox pays only limited attention to supply chain aspects and the water footprint concept.

\section{Charting Our Water Future}

Charting Our Water Future is a report of the Water Resources Group on the possibilities to close the growing gap between (blue) water supply and demand by the 2030 [80]. The report provides an analytical framework to facilitate decision-making and investment in measures increasing supply and improving water productivity. As a key tool, the 'water-marginal cost curve' is presented, which provides a microeconomic analysis of the cost and potential of a range of existing technical measures to close the projected gap between demand and supply within a particular basin area. The report offers case studies from four countries with drastically different water issues together with an extensive list of assessed measures.

\section{Relationship Between Water, Carbon and Ecological Footprints}

A "footprint" in general has become known as a quantitative measure showing the appropriation of natural resources or pressure on the environment by human beings. The water-footprint concept is part of a larger family of concepts that have been developed in the environmental sciences over the past decade. From this point of view water footprint is analogous to carbon and ecological 
footprints. Methodologically there are many similarities between the different footprints, but each has its own peculiarities related to the uniqueness of the substance considered [81]. The features of water, carbon ecological and nitrogen footprints are shown in
Figure 12. Recently, the nitrogen footprint was introduced as a tool to measure the amount of nitrogen released into the environment in relation to consumption [82].

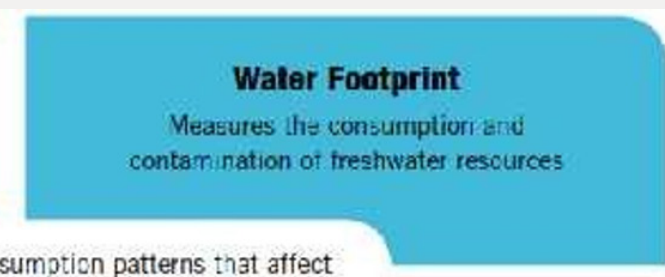
tarth's natural resources and carry ng capacity

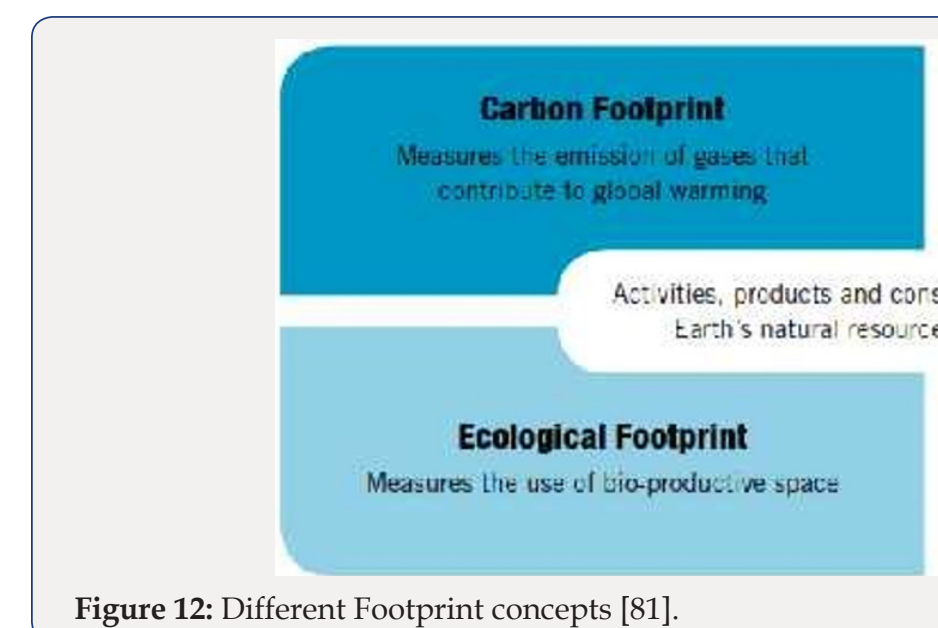

Figure 12: Different Footprint concepts [81].
The carbon footprint measures the amount of greenhouse gases produced, measured as carbon dioxide equivalents (in tons). The water footprint measures water use (in cubic meters per year). Carbon footprint addresses the issue of climate change, the water footprint relates to the issue of freshwater scarcity. In both cases, a supply-chain perspective is promoted. However, for a carbon emission it doesn't matter where it happens, but for a water footprint it does matter. A carbon emission at one place can be offset by carbon emission reduction or sequestration in another place, which is not true for water footprint. One cannot reduce the local impact of water use in one place by saving water in another place.

\section{Ecological Footprint}

Ecological footprint was introduced in the 1990s which denotes the area (hectares) needed to sustain a population, the water footprint represents the water volume (cubic meters per year) required [83-85]

About ten years later a water footprint concept was launched to measure the human appropriation of the globe's freshwater resources. Although both concepts have different roots and measuring methods differ in some respects, the two concepts have in common that they translate human consumption into natural resource use. The ecological footprint measures everything in use of space (in hectares), whereas the WF measures the total use of freshwater resources (in cubic meters per year) [86]. The three indicators are complementary, since they measure completely different things. Most typical for the water footprint is the importance of specifying space (region) and time. This is necessary because the availability of water highly varies in space and time, so that water appropriation should always be considered in its local context [57].

\section{Water Footprints in Life Cycle Assessments}

Life Cycle Assessment (LCA) is a methodology for assessing the environmental performance of a product or service over its life cycle from cradle to grave and addresses basically all environmental impacts caused by the use of fossil fuels and other natural resources and of the emission of harmful substances to air, water and soil. Elementary materials and energy flows are quantified in a Life Cycle Inventory (LCI), while environmental impacts from resource use and emissions are quantified in a Life Cycle Impact Assessments (LCIA) for 'impact categories' such as ozone depletion, climate change, acidification and eutrophication, and higher-level impact categories such as human health, ecosystem quality and resource depletion.

In addition to these quantifications of overall environmental impact, LCIA also allows for the detection of environmental hot spots in production and supply chains, as a basis for optimising the environmental performance of a particular product or service. This all makes LCA a potential tool for assessing the environmental sustainability of products regarding water also and thus it is a potential alternative to the Water footprint network's water footprint approach. However, traditionally only the grey water footprint is covered by LCA, through the assessment of the emission of harmful substances to water according to impact categories such as eutrophication and aquatic toxicity. Until recently, water use was largely neglected in LCAs. Methods for taking the impacts of blue water use into account are now being developed, while green water is hardly considered at all [61,87-89].

Many types of damages, such as acidification or toxicological or eco- toxicological impacts on humans and ecosystems, often are regional or local impacts, making it important to evaluate them in their geographic context. In current LCA approaches, such 
non-global impacts are often calculated on a continent or country basis. Regionalization is therefore recognised as an important step towards improving the accuracy and precision of LCA results. As also the assessment of water use requires regional distinction, the current research on the integration of blue water use in LCAs takes regionalization into account. The impact of blue water use is often represented by a water withdrawal or consumption to availability ratio in a catchment area, so water from a water body that is overexploited would have a higher weighting than water from one that is under-utilized.

In May 2012, a new operational LCA method was launched called the 'IMPACT World+'. This method addresses both water use and regionalization [90-92]. The method assesses worldwide impacts of blue water consumption on a watershed level on aspects such as human health and aquatic and terrestrial ecosystem quality. Together with the calculation of regionalized impacts of emissions to water, using traditional LCA impact categories, the new method addresses blue water scarcity as well as water pollution in a spatially differentiated way.

The LCA approach to water footprints is also adopted in the development of the ISO standard 14046, which is to provide a specification of requirements and guidelines to assess and report on the water footprints of products, processes and organisations, based on LCAs [93-95]. However, it is difficult to predict the extent to which recent developments of the integration of water footprint indicators in LCAs may lead to practicable tools that could, for instance, be used by companies to assess their water footprints and to detect the unsustainable hot spots along their production and supply chains.

\section{Groundwater Footprint}

Gleeson et al. [96] have launched the 'groundwater footprint' concept, which reveals the water balance of global aquifers. According to this concept, the water balance between groundwater aquifer inflows and outflows is converted to a surface area size which is called the 'groundwater footprint' and can be compared to the surface area of the groundwater aquifer.

Groundwater stress occurs if the footprint area is larger than the area of the aquifer itself and varies in severity depending on the ratio between the area of the footprint and the area of the aquifer. The footprint only addresses 'hydrologically active' aquifers that are replenished, and therefore does not include fossil groundwater. The groundwater footprint concept does not relate groundwater use to consumption of products via production and supply chains. Gleeson et al. conclude that at least $20 \%$ of the world's 'active' aquifers are overexploited - some of them heavily and that currently 1.7 billion people live in areas with groundwater stress.

This new concept can complement the water footprint sustainability assessment that focuses on water balances of catchment areas. Groundwater aquifers have different geographical boundaries from those of catchment areas, although they are hydrologically related to these areas. Water stress in catchment areas may cause groundwater depletion. Therefore, there is a large geographical overlap between catchment areas with water stress and groundwater aquifers with water stress. The groundwater footprint approach is useful for water footprint assessments as it maps areas with groundwater scarcity in addition to catchment areas with water scarcity. This also implies that the source of the water used (surface water, shallow groundwater or deep groundwater) is relevant information to determine the scope of the environmental impact.

\section{Environmental Impacts of a Water Footprint}

The main environmental impacts related to a water footprint are listed below:

a) For blue water, the environmental impacts will be in the form of polluted water discharges to river, reduced water levels in rivers and lakes, reduced groundwater levels, and a reduced capacity to assimilate pollutants emitted to water. This, in turn, would lead to a reduced availability of good quality blue water to other users and the ecosystem.

b) For green water, when it is used by water-intensive crops evaporating more than the natural vegetation, the environmental impacts may be a reduced run-off and infiltration, leading to a reduced availability of blue water with effects as described above.

c) For the emission of pollutants to water, the environmental impacts may consist of the pollution of surface water and groundwater, leading to human health risks and possible degradation of ecosystem.

All these impacts, together, lead to problems of water quantity and quality, and impact on humans and ecosystem worldwide. According to the OECD Environmental Outlook to 2050 [97] increasing water demand will exacerbate water stress in many river basins, particularly in densely populated areas in rapidly developing economies. More river basins are projected to come under severe water stress by 2050 . The number of people living in stressed river basins is expected to increase from 1.6 billion in 2000 to 3.9 billion by 2050 , equalling over $40 \%$ of the world population by then, almost the entire population of South Asia and the Middle East and large shares of the population of North China.

In many regions of the world, groundwater is being exploited faster than it can be replenished, leading to increasing groundwater depletion. Gleeson et al. [96] estimated that the size of the global groundwater footprint is currently about 3.5 times the actual area of aquifers, and that about 1.7 billion people live in areas where groundwater resources are under threat. It is found that over $20 \%$ of groundwater aquifers are overexploited. The quality of surface water is expected to deteriorate in the coming decades, caused by 
different groups of pollutants, such as micro-pollutants, pesticides and nutrient overloads from agriculture and poor wastewater treatment of industrial wastes.

The OECD Environmental Outlook to 2050 [97] assessed the consequences of nutrient overloads, which were found to be increased eutrophication, biodiversity loss and disease. For example, the number of lakes at risk of harmful algal blooms is expected to increase by $20 \%$ in the first half of this century. The occurrence, frequency, duration and extent of oxygen depletion and harmful algal blooms in coastal zones are projected to increase as rivers discharge rapidly increasing amounts of nutrients into the sea. Harmful algal blooms may damage ecosystems, fish stocks and fishery opportunities, and pose a danger to human health.

A water footprint assessment does not cover all water-related problems connected to production processes, as it only addresses water use in volumes and water pollution. For instance, the impact of production processes on river discharge patterns and flooding, and the morphological changes, such as dams and canalisations, are not assessed. Hoekstra et al. [66] developed a method to include temporal aspects in their comparisons between blue water use and water availability at a monthly basis for the world's major river basins. Effects of climate change on availability, in time and place, of green and blue water could be included in a water footprint sustainability assessment.

Furthermore, the issue of people lacking access to safe drinking water and adequate sanitation, is not addressed in the water footprint approach, since this often does not concern physical (blue) water scarcity, but economic water scarcity [98,99].

\section{Strategies to Reduce Environmental Impact}

The severity of the environmental impact related to a water footprint component depends on the size of the footprint and its spatial and temporal context. It is determined by the contribution of the footprint component to water stress or pollution in the related catchment and sub-catchment areas compared to the overall degree of water stress or pollution. Often, multiple users are responsible for water stress and pollution in those areas; this implies that reducing the size of those footprint components related to water stressed or polluted areas often is not enough to solve the existing water problems. To achieve a significant reduction in water stress or pollution in catchment and sub-catchment areas, often a more comprehensive approach is needed, involving all major water users in those areas. The impacts related to a water footprint may be reduced along the following complementing strategies as shown in Figure 13.

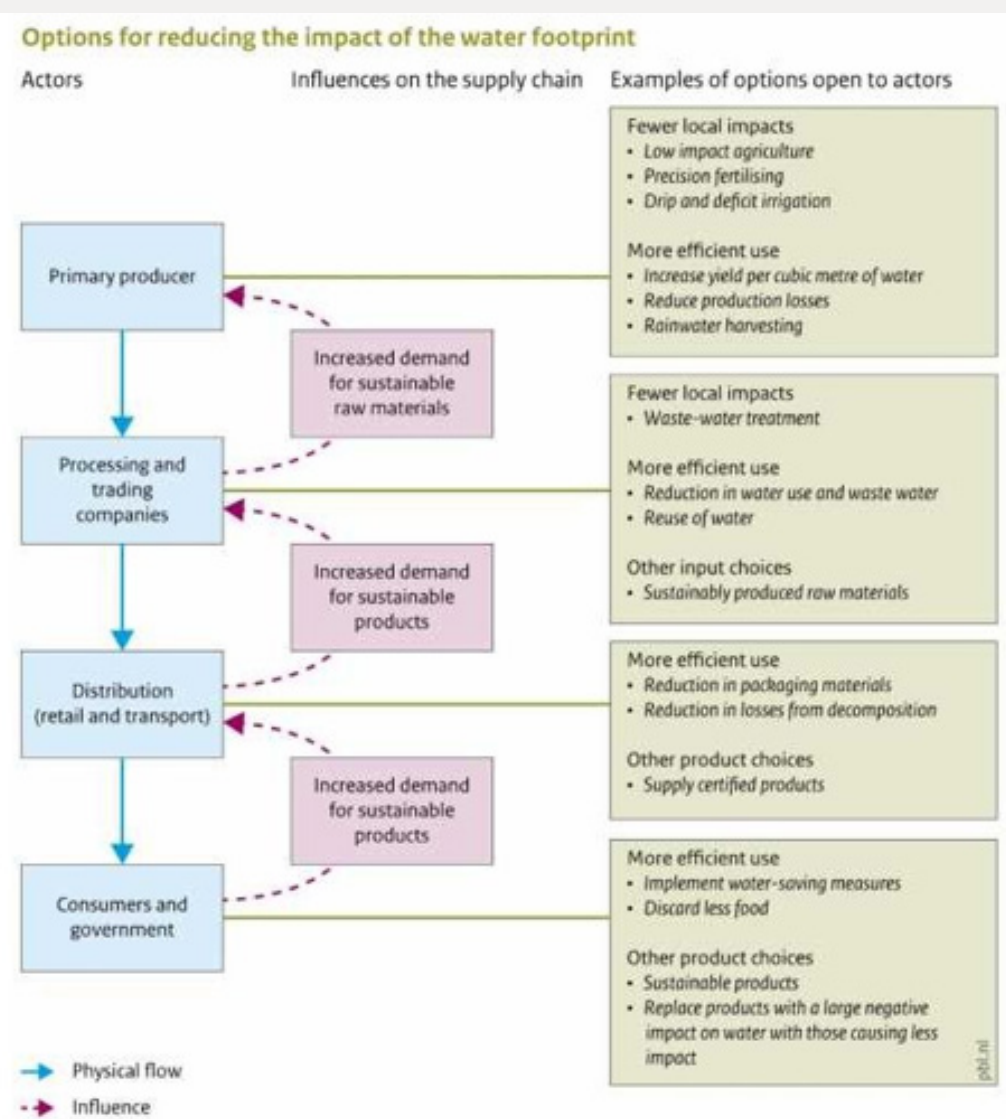

Figure 13: Options to reduce the negative impacts of water footprint [40]. 
Options to reduce the negative impacts related to a water footprint can be found in all steps along the production and supply chains and all the players have to play their roles. Some of the measures which can be adopted by consumers/community, business organizations and government agencies are outlined below [57].

\section{Consumers/Community}

Application of WF concept is important for consumers to use water economically in order to avoid the unnecessary wastage of water. Some of the following measures for water reduction are worth implementing. It is necessary to make the distinction between direct and indirect water footprints. Direct water footprint is that where the consumer is using water for daily needs like drinking, cooking food, flushing toilets, bathing, laundry, etc.; whereas indirect use encompasses many things. Just to give an example drinking coffee. In this example direct water use will involve water used for making a cup of coffee, whereas indirect water use means water used for cultivation of coffee. Some of the measures that could be adopted by consumer are:

\section{Direct Water Footprint}

Installation of water saving toilets, water-saving showerhead, closing the tap during teeth brushing, using less water in the garden and by not disposing medicines, paints or other pollutants through the sink. These measures will fall in the category of reduction in direct water footprint.

\section{Indirect Water Footprint}

The indirect water footprint of a consumer is generally much larger than the direct one. A consumer has basically two options to reduce indirect water footprint. One option is to substitute a consumer product that has a large water footprint by a product that has a smaller water footprint. Examples: eat less meat or become vegetarian, drink tea instead of coffee, or even better drink plain water. Not wearing cotton but artificial fibre clothes saves lot of water. The second option is to stick to the same consumption pattern but to select the cotton, beef or coffee that has a relatively low water footprint or that has its footprint in an area that doesn't have high water scarcity. However, this is possible when consumers have proper information to make that choice. Since this information is generally not available in the world of today, an important thing consumer can do now is to ask product transparency from businesses and regulation from governments. When information is available on the impacts of a certain article on the water system, consumers can make conscious choices about what they buy [40].

\section{Business}

For business organizations the concept of water footprint is important for the following reasons. a) Environmental awareness and strategy to protect the environment is often part of 'corporate social responsibility'. Reducing the water footprint can be part of the environmental strategy of a business, just like reducing the carbon footprint.

b) Many businesses actually face serious risks related to freshwater shortage in their operations or supply chain e.g. how can a company in jean manufacturing survive without continued supply of water to the cotton fields?

c) To meet government regulations on water usage and water pollution standards.

d) Incorporation of water footprint strategy may be considered as an opportunity to reinforce the corporate image or to strengthen the brand name.

In case of business the direct water footprint will involve water consumption during production whereas indirect WF will be water consumption during supply chain. Businesses can reduce their direct water footprint by saving water during production and bringing water pollution to zero by using the strategy of reduce, recycle and treat before disposal. WF analysis is therefore important to achieve Zero discharge during production. Indirect WF during supply chain is not under the control of business, therefore, may be difficult to achieve. However, by making agreements with their suppliers with certain standards can help to reduce supply chain water footprint and making supply chain fully transparent to consumers. Among the various alternative or supplementary tools that can help improving transparency are: setting quantitative water-footprint reduction targets, benchmarking, product labelling, certification and water footprint reporting [40].

\section{Government Agencies}

Water scarcity is posing threats particularly in many developing countries. This is mainly due to fact that governments are not aware the principles of water management. It is time that Government in each country frame rules and regulations and set policies for water conservation at national level. WF concept is therefore important for any government agencies. Governments should engage with consumers and businesses to work towards sustainable consumer products. National water footprint accounting should be a standard component in national water statistics and provide a basis to formulate a national water plan and river basin plans that are coherent with national trade policy and national environmental policy.

\section{Water Footprint Certification and Labelling}

Certification and labelling are potential instruments to promote sustainable water use and to reduce the impact related to the water footprint of business organisations, products and consumers. Certification and labelling schemes are aimed to 
provide assurance that certain criteria are being met, with respect to production methods and product characteristics. This also includes schemes that operate within a supply chain - business to business-and those aimed at communicating product quality to consumers. Certification and labelling are essential communicative tools to create awareness along the supply chain, consumers and government authorities.

Many existing certification and labelling schemes address environmental issues, but only a few include water use, and none cover the full life cycle of a product to reflect the total impact on water footprint. There is currently no single scheme that addresses all of the water issues that would need to be covered. According to Richter [100] there are two main reasons for a company to be involved in water certification:

a) To encourage water efficiency and good water management;

b) To support the corporate reputation regarding social responsibility and sustainability.

\section{Certifying Organization}

Alliance for Water Stewardship the Alliance for Water Stewardship is developing the International Water Stewardship Standard, a performance standard that can be used globally to certify certain water users who voluntarily practice sustainable water management [101-103]. The standard is aimed at companies that use significant amounts of water in their operations. To qualify for certification, applicants will be required to measure their direct and indirect water consumption and other physical and chemical characteristics in the drainage basins along their production and supply chains. The standard should not disadvantage small and medium-sized enterprises or enterprises in least developed countries.

This means that any application of the standard should be both practical and feasible. The AWS is following the ISEAL Code of Good Practices, which is aimed to ensure that voluntary standards are effective and accessible and bring about positive social, environmental and economic effects. AWS intends to align the reporting component of its standard with indicators of the Global Reporting Initiative to the greatest extent possible.

\section{European Water Partenership}

Similar to the development of the International Water Stewardship Standard, the European Water Partnership has developed a European Water Stewardship (EWS) standard for businesses and agriculture to assess, verify and communicate sustainable water management practices at operational and river basin levels [104-106]. The standard is valid on a global scale but based on local assessments with a focus on Europe. Supply-chain and water footprint aspects are covered by criterion 4.2 of the current version of the standard, stating that 'Water management in the supply chain shall be evaluated on long term.' and that 'The purchase of products and material from water sustainable suppliers shall be achieved'.

\section{Conclusion}

Many authoritative scientific reports and opinions of experts in water management studies point out the grave situation of water scarcity world is going to face in the near future. This will be further exasperated by inequitable regional distribution of water in many parts of world. The other problem associated with water scarcity is the water pollution and for various reasons this has reached to an alarming level in some parts of world. Since water is essential for all human activities and to maintain the eco-system it is time that everyone considers water as a precious commodity and manage its use in a sustainable way.

Among the various tools developed for sustainable water management, virtual water and water footprint concepts are gaining popularity. The virtual water concept is more suited for application in international trade where it is emphasized that one of the ways to face the problem of water scarcity is to import the water intensive products from water rich countries. The water footprint concept is applied in local context for sustainable water management.

There is a correlation between water footprint, carbon footprint and ecological footprint except the parameters considered are different in each concept. Water footprint emphasizes on quantitative water use in terms of different evaporative processes. The environmental impact in water footprint concept is correlated with the grey water expressed in terms of dilution water required to assimilate the polluting impurities to the acceptable standard. However, this has been criticized based on two facts firstly, in many countries grey water is used for agriculture and secondly many industries particularly the textile and fashion industry are following the concept of zero water discharge for recycling of polluted water. It is expected that as the water footprint concept further develops, the criticism related to the accounting of environmental impact would become clearer.

\section{References}

1. Towards sustainable water use in cotton supply chain, water footprint.

2. water crises are a top global risk/World Economic Fourm.

3. Water crises food-land-water WBCSD.

4. The state of Apparel sector, Special Report 2015 Water-Global Leadership Award in Sustainable.

5. Shrinking Aral Sea-NASA Earth Observatory.

6. Fashion: The Thirsty Industry.

7. Whitney Bauck (2017) If we can't make the fashion industry more sustainable, we may end up eating our clothes. 
8. Area of earth http://www.universetoday.com/25756/surface-area-ofthe-earth/EarthScience Chapter 4 earth's water- Rojo5th.

9. www.rojo5th.net>science, pdf.

10. What we drink.

11. Where is earth's water located.

12. Gleick PH (1996) Water resources in Encyclopaedia of climate and weather, Oxford Press, New York, USA, 2: 817-823.

13. UN (2003) World Water Crisis Due to Leadership Inertia, ENV'T NEWS SERV.

14. HL Saeijs, MJ Van Berkel (1995) Global Water Crisis: The Major Issue of the $21^{\text {st }}$ Century. A Growing and Explosive Problem 5(4): 26-40.

15. Peter Schulte (2013) The Great Lakes Water Agreement in THE WORLD'S WATER.

16. Moude Barlow (2008) Blue covenant, The global water crisis and the coming battle for right to water. The New Press, pp. 208.

17. Somini Sengupta (2006) India Digs Deeper, but Wells Are Drying Up.

18. Somini Sesngupta (2006) Often Parched India Struggles to Tap the Monsoon, NY TIMES.

19. Katherine McDonald (2011) Women and the Right to Water (High Level Panel), UN Human Rights Counsel Session 18.

20. Richard Black (2010) Water Map Shows Billions at Risk of Water Insecurity, BBC NEWS.

21. Borghild Tønnessen Krokan (2013) Analysis: A Right to Water NORWEGIAN FORUM FOR ENVIRONMENT AND DEVELOPMENT, http:// www.forumfor.no/Artikler/6056.html.

22. United Nations News Centre, www.fao.org $>$ climate change $>$ news.

23. Hake Mark, Robert Miller Blackwell, Zoe Knight, Luis Prieto (2015) Water scarcity and climate change-Pacific institute, www.pacinst org $>$ reports $>$ full report $p d f$.

24. The World's Water Stresses Sustainable Water Management in the Face of Climate Change (2011) http://www.pacinst.org/press_center/pr ess_ releases/worlds_water_vol_7.pdf.

25. An interview with Alexandra Cousteau-Experince life, https:// experience life.com $>$ article.

26. Jouni Paavola, Climate Change, Water and Poverty in the Morogoro Region, Tanzania, www.academia.edu>climate.

27. Water scarcity/international decade for Action Water for Life 20052015, www.un.org >waterforlifedecade>scare city.

28. Allan JA (1994) Overall perspectives on countries and regions. In: Rogers P, Lydon P (Eds); Water in the Arab World: perspectives and prognoses, Harvard University Press, Cambridge, Massachusetts, USA, pp. 65-100.

29. Virtual water, Maria J Beltran (2017) http://www.oxfordbibliographies. com/virtual water.

30. What does virtual water mean? www.definitions.net/definitions/virtual water.

31. Helmar Schubart (2018) The virtual water and water footprint concepts, acatech MaTerialien-nr.

32. Virtual water trade http://waterfootprint.org.

33. Hoekstra AY (2003) Virtual water trade, Proceedings of the International Expert Meeting on virtual water trade, IHE Delft, The Netherlands.

34. Hoekstra AY, Chapagain AK (2008) Globalization of water: Sharing the planet's freshwater resources. Blackwell Publishing Ltd, Oxford, UK.

35. Virtual water http://waterwiki.net/virtual water.

36. Virtual water http://en.m.wikipedia.org
37. Hoekstra AY, Hung PQ (2002) Virtual water trade: A quantification of virtual water flows between nations in relation to international crop trade, IHE Delft, Delft, Value of Water Research Report Series No.11, IHE, Delft, the Netherlands.

38. Hoekstra AY (2013) The water footprint of modern consumer society.

39. J Chenoweth, M Hadjikakou, C Zoumides (2014) Quantifying the human impact on water resources: A critical review of the water footprint concept. Hydrol Earth Syst Sci 18: 2325-2342.

40. Witmer MCH, Cleij P (2012) Water Footprint: Useful for sustainability policies? PBL Netherland environmental assessment agency.

41. Hoekstra AY (2008) Measuring your water footprint. What's next in water strategy leading perspectives.

42. M Aldaya, Mesfin M Mekonnen (2011) The water footprint assessment manual: Setting the global standard, Earthscan publishing, London.

43. Chapagain AK, Hoekstra AY (2004) Water footprints of nations: Main Report, Value of water research Report.

44. (2013) Water footprint and sustainable water utilities project 4378, Water research foundation.

45. Chapagain AK, Hoekstra AY, Savenije HHG, Gautam R (2005) The water footprint of cotton consumption, Value of Water Research Report Series.

46. Hoekstra AY (2004) Water footprints of nation.

47. Hoekstra AY, Chapagain AK (2008) Globalization of water, WileyBlackwell Publishing.

48. Hoekstra AY (2011) A comprehensive introduction to water footprints.

49. Hoekstra AY, Chapagain AK (2007) Water footprints of nations: Water use by people as a function of their consumption pattern.

50. Hoekstra AY, Mekonnen MM (2012) The water footprint of humanity.

51. Water footprint https://en.m.wikipedia.org.

52. Water footprint, https://waterfootprint.org/en/water- footprint.

53. Falkenmark M, Rockström J, Karlberg L (2009) Present and future water requirements for feeding humanity. Food Security 1(1): 59-69.

54. Mekonnen MM, Hoekstra AY (2011) The green, blue and grey water footprint of crops and derived crop products. Hydrol Earth Syst Sci 15: 1577-1600.

55. Chapagain AK, Tickner D (2012) Water footprint: Help or hindrance? Water Alternatives 5: 563-581.

56. Chapagain AK, Hoekstra AY, Savenije HHG, Gautam R (2006) The water footprint of cotton consumption: An assessment of impact of worldwide consumption of cotton products on the water resources in the cotton producing countries. Ecological economics 60(1): 186-203.

57. Frequently asked questions-Water footprint network, waterfootprint org $>$ water footprint $>$ faq

58. Velázquez E, Madrid C, Beltran MJ (2011) Rethinking the Concepts of Virtual Water and Water footprint in Relation to the ProductionConsumption Binomial and the Water- Energy Nexus. Water Resour Manag 25(2): 743-761.

59.Water footprinting: Managing water resources, http://www. waterfootprint.org/Reports pdf.

60.SABMiller and WWF-UK (2009) Water Footprinting: Identifying \& Addressing Water Risks in the Value Chain.

61. Berger M, Finkbeiner M (2010) Water Footprinting: How to Address Water Use in Life Cycle Assessment? Sustainability 2: 919-944.

62. Schwarzenbach RP, Egli T, Hofstetter TB, Von Gunten U, Wehrli B (2010) Global Water Pollution and Human Health. Annual Review of Environment and Resources 35: 109-136. 
63. Wichelns D (2010) Virtual Water: A Helpful Perspective, but not a Sufficient Policy Criterion. Water Resour Manag 24(10): 2203-2219.

64. Wichelns D (2010) Virtual water and water footprints offer limited insight regarding important policy questions. Int J Water Resourc D 26(4): 639-651.

65. Van Oel PR, Mekonnen MM, Hoekstra AY (2008) The external water footprint of the Netherlands: quantification and impact assessment, Value of Water Research Report Series, UNESCO-IHE Institute for Water Education, Delft, The Netherlands.

66. Hoekstra AY, Mekonnen MM, Chapagain AK, Mathews RE, Richter BD (2012) Global Monthly Water Scarcity: Blue Water Footprints versus Blue Water Availability. PloS ONE 7(2).

67. Liu C, Kroeze C, Hoekstra AY, Gerbens-Leenes W (2012) Past and future trends in grey water footprints of anthropogenic nitrogen and phosphorus inputs to major world rivers. Ecological Indicators 18: 4249.

68. Ruth Mathew (2013) Water footprint and sustainability assessment.

69. OPEN EU (2012) One Planet Economy Network.

70. EUREAPA (2012) Scenario Modelling and Policy Assessment Tool, https://www.eureapa.net/.

71. WBCSD (2012) Global Water Tool 2011, http://www.wbcsd.org/workprogram/sector-projects/water/global- water-tool.aspx.

72. GEMI@ Local Water Tool ${ }^{\mathrm{TM}}$ (LWT), http://www.gemi.org/localwatertool/

73. Global Environmental Management Initiative, http://www.gemi.org/ gemihome.aspx, 74. Ceres Aqua Gauge, http://www.ceres.org/issues/ water/aqua-gauge

74. The Water Risk Filter, http://waterriskfilter.panda.org/

75. Center for Sustainable Organizations, http://www. sustainableorganizations.or g/index.html

76. WRI and Partners Launch Aqueduct Alliance to Measure, Map and Report on Global Water Risk, http://www.wri.org/press/2011/08/release

77. Aqueduct. Measuring and Mapping Water Risks, http://insights.wri. org/aqueduct

78. GWP Toolbox Integrated Water Resources Management, http://www. gwptoolbox.org/

79. Charting Our Water Future, The 2030 Water Resources Group. http:// www.mckinsey.com/Client_Serv ice/Sustainability/Latest_thinking/ Char ting_our_water future.

80. Ercin AE, Hoekstra AY (2012) Carbon and water footprints: Concepts, methodologies and policy responses, UNESCO Publication, www.unesco. org $>$ new $>$ side-publications

81. Leach AM, Galloway JN, Bleeker A, Erisman JW, Kohn R, et al. (2012) A nitrogen footprint model to help consumers understand their role in nitrogen losses to the environment, Environmental Development 1(1): 40-66.

82. Rees WE (1992) Ecological footprints and appropriated carrying capacity: What urban economics leaves out. Environment and Urbanization 4(2): 121-130.

83. Wackernagel M, Rees WE (1997) Perceptual and structural barriers to investing in natural capital, Economics from an ecological footprint perspective. Ecological Economics 20(1): 3-24.

84. Wackernagel M, Rees W (1996) Our ecological footprint: Reducing human impact on the earth, New Society Publishers, Gabriola Island BC, Canada.
85. Hoekstra AY (2007) Human appropriation of natural capital: Comparing ecological footprint and water footprint analysis, Value of water Research reports series, UNESCO-IHE.

86. Jeswani HK, Azapagic A (2011) Water footprint: Methodologies and a case study for assessing the impacts of water use. Journal of Cleaner Production 19(12): 1288-1299.

87. Jefferies D, Muñoz I, Hodges J, King VJ, Aldaya M, et al. (2012) Water Footprint and Life Cycle Assessment as approaches to assess potential impacts of products on water consumption. Key learning points from pilot studies on tea and margarine. Journal of Cleaner Production 33: 155-166.

88. ACLCA (2012) Regional life cycle impact assessment characterization models. Life Cycle Assessment IX conference 2009.

89. IWP (2012) IMPACT World+TM, http://www.impactworldplus.org/en/ in dex.php

90. ILCC (2012) Launch of IMPACT World+, the first worldwide regionalized life cycle impact assessment method, International Life Cycle Chair, Montréal, Canada.

91. Rosenbaum RK, Jolliet O, Bulle C (2012) Quantification of characterization factor uncertainties in the IMPACT World+ LCIA method, Presentation, Technical University of Denmark, University of Michigan \& CIRAIG.

92. Humbert S (2010) ISO 14046: water footprint. Summary of the project, Presentation, Quantis, Switzerland.

93. Postle M, George C, Upson S, Hess T, Morris J (2011) Assessment of the efficiency of the water foot printing approach and of the agricultural products and foodstuff labelling and certification schemes, Risk \& Policy Analysts Limited, London, United Kingdom.

94. Part A (Assessment) http://www.rpaltd.co.uk/documents/W aterFootprintingPartA.pdf.

95. Part B (Recommendations for Certification) http://ec.europa.eu/ environment/water/ quantity/pdf/Final\%20Report $\% 20$ Part $\% 20$ B\%20\%20clean\%2019\%20Sept_2 011.pdf.

96. ISO (2012) ISO/CD 14046. Life cycle assessment - Water footprint -Requirements and guidelines.

97. Gleeson T, Wada Y, Bierkens MFP, Van Beek LPH (2012) Water balance of global aquifers revealed by groundwater footprint. Nature 488: 197200 .

98. OECD (2012) OECD Environmental Outlook to 2050: The Consequences of Inaction, OECD Publishing.

99. Rijsberman FR (2006) Water scarcity: fact or fiction? Agricultural Water Management 80(1-3): 5-22.

100. Molden D (2007) Water for food. Water for live, Summary, International Water Management Institute.

101. Richter BD (2009) Sustainable water use: Can certification show the way? Innovations 4(3): 119-139.

102. Alliance for Water Stewardship, http://www allianceforwaterstewardshi p.org/

103. The AWS International Water Stewardship Standard. FIRST DRAFT FOR STAKEHOLDER INPUT, Alliance for Water Stewardship.

104. ISEAL (2012) ISEAL Alliance, http://www.isealalliance.org/European Water Partnership, http://www.ewp.eu/

105. EWP (2011) European Water Stewardship Standard v4.8, European Water Partnership.

106. European Water Stewardship (EWS) Certification Scheme. Certification Outline, European Water Partnership. 


\section{(C) (i) This work is licensed under Creative}

To Submit Your Article Click Here: Submit Article

DOI: 10.32474/LTTFD.2018.02.000150

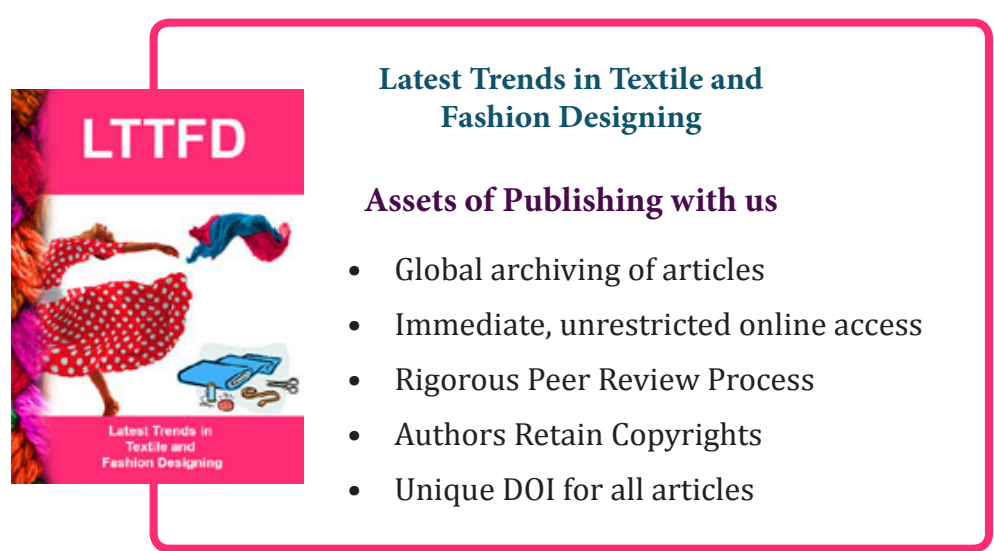

